\title{
Extreme waves in the southern Baltic Sea
}

\section{Olas gigantes en la parte sur del mar Báltico}

\author{
Wojciech Sulisz*, Maciej Paprota, Anna Reda \\ Institute of Hydroengineering of the Polish Academy of Sciences, Kościerska 7, 80-328 Gdańsk, Poland. \\ * Corresponding author. E-mail: sulisz@ibwpan.gda.pl
}

\begin{abstract}
Freak waves are unique phenomena that appear unexpectedly on the ocean surface. These waves are not only a danger to fishermen and yachtsmen, but are also capable of damaging large vessels and offshore and coastal structures. The available field measurements that provide insight into the origin and physics of freak waves are very limited. The main objective of the present study was to analyze a unique set of wave data comprising 19,025 wind-wave records from the southern Baltic Sea to provide information on the occurrence, parameters, and prevailing conditions of the formation of freak waves. The complex nature of freak waves was investigated by obtaining spectral and statistical parameters of freak-wave-prone sea states using a wide set of tools. The study revealed a large number of freak-type waves, including waves over $12 \mathrm{~m}$ high. The study indicates that these hazardous waves may even exceed $20 \mathrm{~m}$ during severe storms in the Baltic Sea. Multi-point wind-wave measurements are needed to provide more information about the physics of freak waves and to eventually develop a prediction or warning system to avoid casualties.
\end{abstract}

Key words: freak waves, extreme storms, wave records, wind-wave analysis.

RESUMEN. Las olas gigantes son fenómenos únicos que aparecen inesperadamente en la superficie del océano. Estas olas no sólo son un peligro para pescadores y navegantes, sino que también son capaces de dañar embarcaciones grandes y estructuras costeras y en alta mar. Son pocas las mediciones de campo disponibles que proporcionan información sobre el origen y la física de las olas gigantes, por lo que el objetivo principal de este estudio fue analizar una base de datos de 19,025 registros del oleaje en la parte sur del mar Báltico para obtener información sobre la frecuencia, los parámetros y las condiciones prevalecientes de la formación de éstas. Para estudiar la naturaleza compleja de las olas gigantes, se obtuvieron parámetros espectrales y estadísticos de los estados de mar propensos a olas gigantes usando varias herramientas. El estudio mostró un gran número de olas gigantes, incluyendo olas de más de $12 \mathrm{~m}$ de altura, y que estas olas pueden sobrepasar los $20 \mathrm{~m}$ de altura durante tormentas severas en el mar Báltico. Se requieren mediciones de oleaje de distintos sitios para recabar mayor información sobre la física de olas gigantes y eventualmente poder desarrollar un sistema de predicción y advertencia para evitar desgracias.

Palabras clave: olas gigantes, tormentas extremas, registros de oleaje, análisis de oleaje.

\section{INTRODUCTION}

Freak waves are probably the most dangerous type of waves that appear on the ocean surface. Accidents and damages caused by extreme waves require a better understanding of the origin and physics of these hazardous waves. Knowledge on freak waves is indispensible for the development of a warning system against the attack of extreme waves on maritime structures or their impact on ships.

Freak-type waves, usually defined as extreme waves of height exceeding twice the significant wave height, are probably one of the most complex phenomena occurring during extreme storms. Recently, considerable progress has been made in modeling of freak waves, their origin, and physical properties. Potential mechanisms of the formation of freak waves are a linear superposition of component waves, wave-current interactions, modulational instability of deepwater wave trains, shallow water effects, crossing seas, and wind effects (Didenkulova and Pelinovsky 2011, Sergeeva et al. 2011, Toffoli et al. 2011, Onorato et al. 2013, Xiao et al. 2013). Many theoretical and experimental studies have

\section{INTRODUCCIÓN}

Las olas gigantes probablemente son las olas más peligrosas que aparecen en la superficie del océano. Debido a los accidentes y daños que causan es necesario tener un mejor conocimiento del origen y la física de estas olas peligrosas. Este conocimiento es indispensable para poder desarrollar un sistema de alerta contra el impacto de olas extremas contra estructuras marítimas y embarcaciones.

Las olas gigantes, definidas como olas extremas cuya altura es más de 2 veces la altura significativa de las olas, son uno de los fenómenos más complejos que se presentan durante tormentas severas. Recientemente, se han logrado avances considerables en el modelado de olas gigantes, su origen y sus propiedades físicas. Los mecanismos potenciales de su formación incluyen la superposición lineal de ondas, la interacción entre olas y corrientes, la inestabilidad modulacional de trenes de olas de agua profunda, los efectos de agua somera, mar cruzado y los efectos del viento (Didenkulova y Pelinovsky 2011, Sergeeva et al. 2011, Toffoli et al. 2011, Onorato et al. 2013, Xiao et al. 2013). Se han realizado varios 
recently been conducted to extend the understanding of freak waves (e.g., Onorato et al. 2006; Sulisz and Paprota 2006, 2011, 2013; Gramstad and Trulsen 2007; Paplińska-Swerpel et al. 2007; Kharif et al. 2009; Bitner-Gregersen and Toffoli 2012; Chabchoub et al. 2012; Adcock and Taylor 2014; Majewski et al. 2014). Further progress in understanding the origin and physics of freak waves can be achieved by the analysis of data sets containing reliable wind-wave measurements. The problem is that available field measurements that provide insight into the origin and physics of freak waves are very limited. In fact, only few studies based on extreme-wave field data have been performed in the past (e.g., Chien et al. 2002, Mori et al. 2002, Silva et al. 2002, Stansell 2004, Sulisz and Paprota 2005, Didenkulova 2010, Montoya et al. 2013).

A unique set of time series of free-surface elevation records is available at the Institute of Hydroengineering of the Polish Academy of Sciences (IBW PAN), Gdańsk. It consists of measurements obtained by Waverider buoys at several locations along the southern Baltic Sea. It comprises more than 19,025 records including storm conditions. The database can provide useful information on extreme storms, extreme waves, and wave events, and eventually help to better define hazards and protection measures against extreme situations. The problem is serious because during a recent field campaign in Polish territorial waters an individual wave of $12 \mathrm{~m}$ in height was measured at a depth of $20.5 \mathrm{~m}$ and the waves in the open sea can be far higher (see, e.g., Soomere et al. 2008). Measurements of such extremely large freak-type waves are good arguments to publicize the problem of extreme waves in the Baltic Sea and to conduct more systematic studies on the origin and physics of freak waves.

In this work, time series of free-surface elevation recorded by Waverider buoys in the southern Baltic Sea are analyzed. The main goal of the study is to analyze wind-wave records from the southern Baltic to provide information on parameters and prevailing conditions of freak wave occurrence. First, the available data sets are described and extreme wave records are defined. The wind-wave records are analyzed with emphasis on extreme storm features. Then, the analysis focuses on individual extreme waves and wave events. The analysis includes a wide range of aspects related to extreme storms and individual extreme waves to collect as much information as possible on the occurrence and features of extreme waves, and to eventually contribute to a future warning system. Finally, conclusions arising from the analysis of wave records are specified.

\section{MATERIALS AND METHODS}

The wind-wave records analyzed in this study were collected by IBW PAN. The measurements of free-surface elevation were conducted in the southern part of the Baltic Sea at the buoy stations located in the vicinity of Lubiatowo (Fig. 1), where the coastline is straight over a long distance. estudios teóricos y experimentales para ampliar el entendimiento de las olas gigantes (e.g., Onorato et al. 2006; Sulisz y Paprota 2006, 2011, 2013; Gramstad y Trulsen 2007; Paplińska-Swerpel et al. 2007; Kharif et al. 2009; BitnerGregersen y Toffoli 2012; Chabchoub et al. 2012; Adcock y Taylor 2014; Majewski et al. 2014). Es posible ampliar aún más el conocimiento del origen y la física de las olas gigantes mediante el análisis de bases de datos de mediciones de oleaje confiables. El problema es que son limitadas las mediciones de campo disponibles que proporcionan información del origen y la física de las olas gigantes, ya que son pocos los estudios que se han llevado a cabo con datos de campo (e.g., Chien et al. 2002, Mori et al. 2002, Silva et al. 2002, Stansell 2004, Sulisz y Paprota 2005, Didenkulova 2010, Montoya et al. 2013).

Un conjunto único de series de tiempo de la elevación de la superficie libre del mar está disponible en el Instituto de Hidroingeniería de la Academia Polaca de Ciencias (IBW PAN) en Gdańsk. Consiste de mediciones obtenidas con boyas de tipo Waverider en varios sitios en la parte sur del mar Báltico. Contiene más de 19,025 registros, incluyendo datos de las condiciones de tormenta. La base de datos proporciona información útil sobre tormentas severas, olas gigantes y eventos de oleaje, información que eventualmente permitirá definir mejor los peligros y las medidas de protección contra situaciones extremas. El problema es serio ya que durante una campaña reciente en aguas territoriales polacas se registró una ola individual de $12 \mathrm{~m}$ de altura a una profundidad de $20.5 \mathrm{~m}$ y las olas en mar abierto pueden ser mucho mayor (ver, e.g., Soomere et al. 2008). Estas mediciones son un buen argumento para difundir el problema de las olas gigantes en el mar Báltico y realizar estudios sistemáticos del origen y la física de éstas.

En este trabajo se analizan las series de tiempo de la elevación de la superficie libre del mar registrada mediante boyas Waverider en la parte sur del mar Báltico. El objetivo principal del estudio es analizar los registros de oleaje para proporcionar información de los parámetros y las condiciones prevalecientes de las olas gigantes. Primero se describen los conjuntos de datos disponibles y se definen los registros de olas gigantes. Las mediciones de oleaje se analizan con énfasis en las características de las tormentas extremas. El análisis luego se enfoca en los eventos de oleaje y las olas gigantes individuales. El análisis incluye una amplia gama de aspectos relacionados con tormentas extremas y olas gigantes individuales para recopilar la mayor cantidad de información posible de la frecuencia y las características de olas extremas y eventualmente poder contribuir a desarrollar un sistema de alerta. Finalmente, se discuten las conclusiones derivadas del análisis.

\section{MATERIALES Y MÉTODOS}

Los registros de oleaje analizados en este estudio fueron recopilados por IBW PAN. Las mediciones de la elevación 


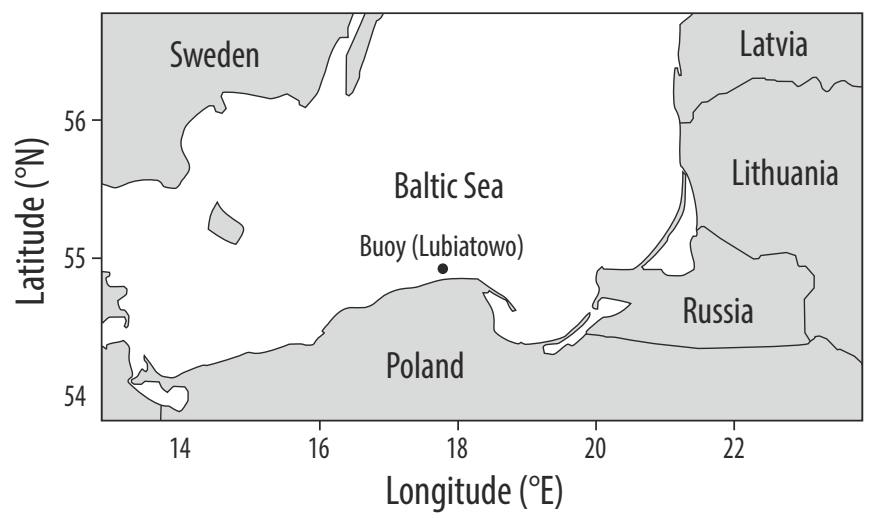

Figure 1. Southern part of the Baltic Sea and location of the study area.

Figura 1. Parte sur del mar Báltico y ubicación del sitio de muestreo.

The measurements were performed using a Directional Waverider (DWR) buoy. The raw data wave record contains 20-min registration of free-surface elevations measured with a frequency of $1.28 \mathrm{~Hz}$. The data were usually collected every hour. The measurement periods varied from a few to several months. The buoy was deployed $5 \mathrm{~km}$ away from the shore at a depth of $20 \mathrm{~m}$. Buoy locations and measurement periods are provided in Table 1 . The wind-wave data sets specified in Table 1 constitute a unique and valuable source of information on wind waves in the southern Baltic Sea. This database is the only available collection of wave measurements taken in Polish territorial waters. The total DWR data set for the period 1996-2002 consists of 19,025 wave records. The highest individual wave measured in the data set is $7.6 \mathrm{~m}$ and the highest significant wave height is $4.0 \mathrm{~m}$. The water depth of $20 \mathrm{~m}$ and wavelengths corresponding to the typical peak periods allow the exclusion of shallow water freak wave generation mechanisms. In a recent field campaign the DWR buoy measured a huge 12-m-high wave at $20.5 \mathrm{~m}$ depth, which provides new arguments for conducting studies on extreme waves and wave events in the Baltic Sea.

The analysis of the data set requires a selection of criteria to define extreme waves and wave records. The problem is

Table 1. Location of buoy (Directional Waverider) stations in the vicinity of Lubiatowo (Poland) and measurement periods.

Tabla 1. Ubicación de las estaciones de mediciones con una boya direccional tipo Waverider en la zona de Lubiatowo (Polonia) y los periodos de medición.

\begin{tabular}{cc}
\hline Latitude, longitude & Measurement period \\
\hline $54^{\circ} 51^{\prime} \mathrm{N}, 17^{\circ} 48^{\prime} \mathrm{E}$ & 28 Oct 1996-27 Feb 1997 \\
$54^{\circ} 53^{\prime} \mathrm{N}, 17^{\circ} 51^{\prime} \mathrm{E}$ & 15 Jan 1998-31 Aug 1999 \\
$54^{\circ} 50^{\prime} \mathrm{N}, 17^{\circ} 48^{\prime} \mathrm{E}$ & 09 Oct 2000-21 Oct 2001 \\
$54^{\circ} 51^{\prime} \mathrm{N}, 17^{\circ} 50^{\prime} \mathrm{E}$ & 30 Aug 2002-04 Dec 2002 \\
\hline
\end{tabular}

de la superficie libre del mar se realizaron en la parte sur del mar Báltico, en las estaciones localizadas en la zona de Lubiatowo (Fig. 1), donde la línea de costa es recta.

Las mediciones se realizaron con una boya direccional tipo Waverider (DWR). El registro de los datos brutos contiene registros de 20 min de la elevación de la superficie libre del mar medida con una frecuencia de $1.28 \mathrm{~Hz}$. Los datos usualmente fueron recolectados cada hora. Los periodos de medición variaron de unos cuantos a varios meses. La boya DWR fue instalada $5 \mathrm{~km}$ de la costa a una profundidad de $20 \mathrm{~m}$. La ubicación de la boya y los periodos de medición se muestran en la Tabla 1. Los conjuntos de datos del oleaje que se presentan en la Tabla 1 constituyen una fuente de información valiosa del oleaje al sur del mar Báltico. Esta base de datos es el único conjunto de mediciones de oleaje disponible para aguas territoriales polacas. La base de datos total para el periodo de 1996 a 2002 consiste de 19,025 registros de oleaje. La ola individual más alta en la base de datos es de $7.6 \mathrm{~m}$ y la mayor altura significativa es de $4.0 \mathrm{~m}$. La profundidad del agua de $20 \mathrm{~m}$ y las longitudes de onda que corresponden a los periodos de máxima altura permiten excluir los mecanismos de generación de olas insólitas en aguas someras. En una campaña reciente, se registró una ola de $12 \mathrm{~m}$ de altura a $20.5 \mathrm{~m}$ de profundidad, lo cual proporciona nuevos argumentos para realizar estudios de olas gigantes y eventos de oleaje extremos en el mar Báltico.

El análisis del conjunto de datos requiere de una selección de criterios para definir las mediciones de eventos de oleaje y olas extremas. El problema no es trivial ya que la formación y propagación de olas gigantes puede depender de factores que afectan el oleaje, incluyendo la severidad de la tormenta, su duración, variación y dirección, etc. En el presente estudio, se escogió la altura significativa de las olas para definir las olas gigantes, ya que es uno de los parámetros más importantes que se usan para describir el oleaje. De hecho, la altura significativa frecuentemente se usa en la descripción y definición de las olas gigantes y en el análisis de la frecuencia de eventos de oleaje extremos y olas gigantes. A partir del estudio realizado por el proyecto denominado MaxWave, las olas extremas en el mar Báltico se describen en términos de la altura máxima $\left(H_{\max }\right)$ y la altura significativa $\left(H_{\mathrm{s}}\right)$ de la ola como sigue (Paprota et al. 2003, Rosenthal y Lehner 2008):

- olas cuya altura es más de 2 veces la altura significativa: $H_{\text {max }} / H_{\mathrm{s}}>2$;

- la altura significativa de las olas es mayor que $1 \mathrm{~m}$ : $H_{\mathrm{s}}>1 \mathrm{~m}$.

El umbral de $1 \mathrm{~m}$ impuesto para la altura significativa es sobrepasado por 4,975 de los registros de olas de tormentas. La aplicación de ambos límites (i.e., $H_{\mathrm{s}}>1 \mathrm{~m} \mathrm{y} H_{\max } / H_{\mathrm{s}}>2$ ) arroja 261 registros de olas gigantes. El número de olas gigantes puede ser subestimada si se toma en cuenta los límites y las desventajas del sistema de medición. De hecho, se subestiman las crestas medidas en condiciones severas 
not trivial because extreme-wave formation and propagation may depend on factors affecting wind waves, including storm severity, its duration and variation, storm direction, etc. In this study, the significant wave height was chosen to define extreme waves, because it is one of the most important parameters used in the description of wind waves. In fact, the significant wave height is widely used to describe and define extreme waves and in the analysis of the occurrence of extreme waves and wave events. Following the studies conducted in the MaxWave project, extreme waves in the Baltic Sea are defined in terms of the maximum wave height $\left(H_{\max }\right)$ and the significant wave height $\left(H_{\mathrm{s}}\right)$ as follows (Paprota et al. 2003, Rosenthal and Lehner 2008):

- waves exceeding twice the significant wave height: $H_{\max } / H_{\mathrm{s}}>2$;

- significant wave height is larger than $1 \mathrm{~m}: H_{\mathrm{s}}>1 \mathrm{~m}$.

The threshold of $1 \mathrm{~m}$ set for significant wave height is exceeded by 4,975 storm wave records. The application of both limits (i.e., $H_{\mathrm{s}}>1 \mathrm{~m}$ and $H_{\max } / H_{\mathrm{s}}>2$ ) results in 261 extreme wave records. The number of extreme wave records may be underestimated taking into account the limits and drawbacks of the applied measuring system. In fact, the wave crests measured during severe conditions are underestimated due to the quasi-Lagrangian motion of the buoy (Magnusson et al. 1999).

\section{RESUlTS}

\section{Analysis of extreme storms}

First, the results from the statistical analysis of the set of the storm and extreme wave records are presented. The relationships between $H_{\max }$ and $H_{\mathrm{s}}$ for the extreme wave records are presented in Figure 2. The number of extreme wave records corresponding to selected ranges of $H_{\max }$ and $H_{\mathrm{s}}$ is presented in the form of histograms.

It is worth noting that one can establish a different set of conditions to define extreme waves, including the ratio of the wave crest height to wave height, the ratio of the crest height to trough height, etc. (e.g., Chien et al. 2002). However, many available definitions are more appropriate for defining episodic waves rather than extreme waves or wave events. Extreme waves considered in the present study can be regarded as the wave events or large waves characterized by the extreme values of the tail of the statistical probability distribution. This means that the extreme wave height is defined in such a way that it is the largest value among a particular sample of wave heights arbitrarily chosen from the population of wave heights.

The direction of extreme waves constitutes an important source of information on the occurrence of extreme waves and wave events. Information on the direction of extreme waves, especially if there is any prevailing direction, is debido al movimiento cuasi-lagrangiano de la boya (Magnusson et al. 1999).

\section{RESULTADOS}

\section{Análisis de tormentas extremas}

Primero se presentan los resultados del análisis estadístico del conjunto de datos de las tormentas y olas extremas. La relación entre $H_{\max }$ y $H_{\mathrm{s}}$ de las olas se muestra en la Figura 2. El número de registros de olas extremas que corresponden a intervalos seleccionados de $H_{\max }$ y $H_{\mathrm{s}}$ se presenta en forma de histogramas.

Cabe mencionar que se puede establecer un conjunto diferente de condiciones para definir las olas gigantes, incluyendo la relación entre la altura de la cresta y la altura de la ola, la relación entre la altura de la cresta y la altura de la depresión, etc. (e.g., Chien et al. 2002). No obstante, varias de las definiciones disponibles son más apropiadas para definir olas episódicas que olas gigantes o eventos de oleajes extremos. En este trabajo las olas extremas pueden considerarse como los eventos de oleaje o las olas grandes caracterizadas por los valores extremos de la cola de la distribución de probabilidad estadística. Esto significa que la altura de ola extrema se define de tal forma que es el valor más alto de una muestra particular de alturas de ola elegida arbitrariamente del conjunto de datos.

La dirección de las olas extremas es una importante fuente de información sobre la frecuencia de olas gigantes y eventos de oleaje extremos. Cualquier información sobre la dirección de olas extremas, especialmente si hay una dirección predominante, es importante desde un punto de vista práctico. La distribución de las direcciones de tormentas y la
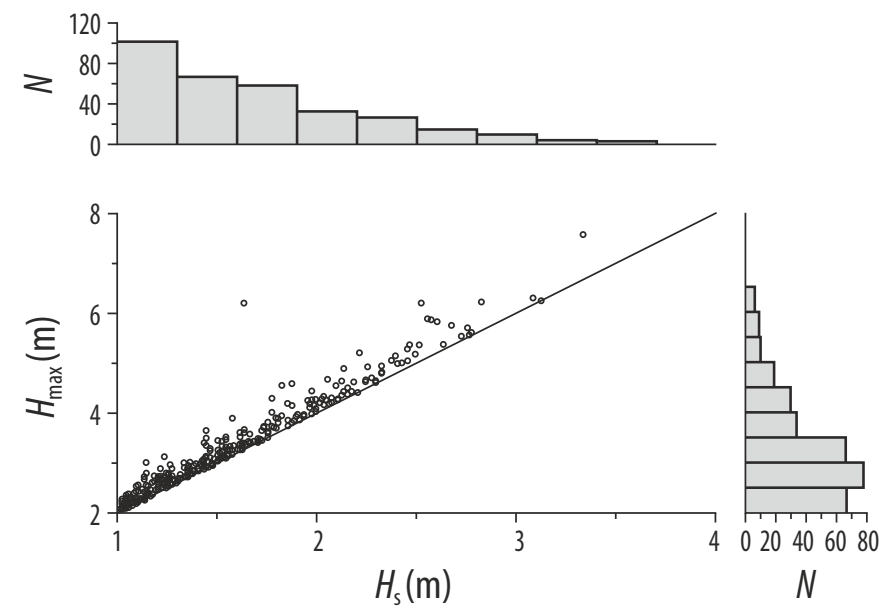

Figure 2. Scatter plot of maximum $\left(H_{\max }\right)$ and significant $\left(H_{\mathrm{s}}\right)$ wave heights with histograms for the extreme waves. $N=$ number of cases.

Figura 2. Diagrama de dispersión de las alturas máximas $\left(H_{\max }\right)$ y significativas $\left(H_{\mathrm{s}}\right)$ de las olas, con histogramas para las olas gigantes. $N=$ número de casos. 
important from a practical point of view. The distribution of storm directions and the corresponding distribution of extreme wave directions for the area of Lubiatowo are presented in Figure 3.

The plots in Figure 3 show that strong storms and extreme waves come mainly from the W-WNW and N-NNE directions. This outcome is interesting and rather nonintuitive. The analysis shows that wave records with $H_{\mathrm{s}}$ exceeding $1.0 \mathrm{~m}$ constitute $26 \%$ of conducted measurements and very strong storms with $H_{\mathrm{s}}$ greater than $2 \mathrm{~m}$ account for $4.4 \%$ of wave records in the analyzed data set. The total set of 261 extreme waves has been observed among 19,025 records, which means that $1.4 \%$ of all records can be considered extreme wave records.

Correlations between parameters affecting a sea state are important sources of information on extreme waves. The description of a sea state is usually presented in terms of wave height and wave period (e.g., Tucker 1991, Leyden and distribución correspondiente de las direcciones de olas extremas para la zona de Lubiatowo se presentan en la Figura 3.

Las gráficas de la Figura 3 muestran que las tormentas fuertes y olas gigantes provienen de las direcciones $\mathrm{W}-\mathrm{WNW}$ y N-NNE. Este resultado es interesante y no intuitivo. El análisis muestra que los registros con una $H_{\mathrm{s}}$ mayor que $1.0 \mathrm{~m}$ constituyen el $26 \%$ de las mediciones realizadas y que las tormentas muy fuertes con una $H_{\mathrm{s}}$ mayor que $2 \mathrm{~m}$ constituyen el $4.4 \%$ de los registros en el conjunto de datos analizado. Se obtuvo un total de 261 olas extremas de entre 19,025 registros, lo que significa que $1.4 \%$ de todos los registros pueden considerarse registros de olas extremas.

Las correlaciones entre los parámetros que afectan un estado de mar son importantes fuentes de información sobre olas extremas. La descripción de un estado de mar generalmente se presenta en términos de la altura y periodo de las olas (e.g., Tucker 1991, Leyden y Dally 1996). La altura significativa $\left(H_{\mathrm{s}}\right)$ y el periodo promedio $\left(T_{\mathrm{m}}\right)$ probablemente son a
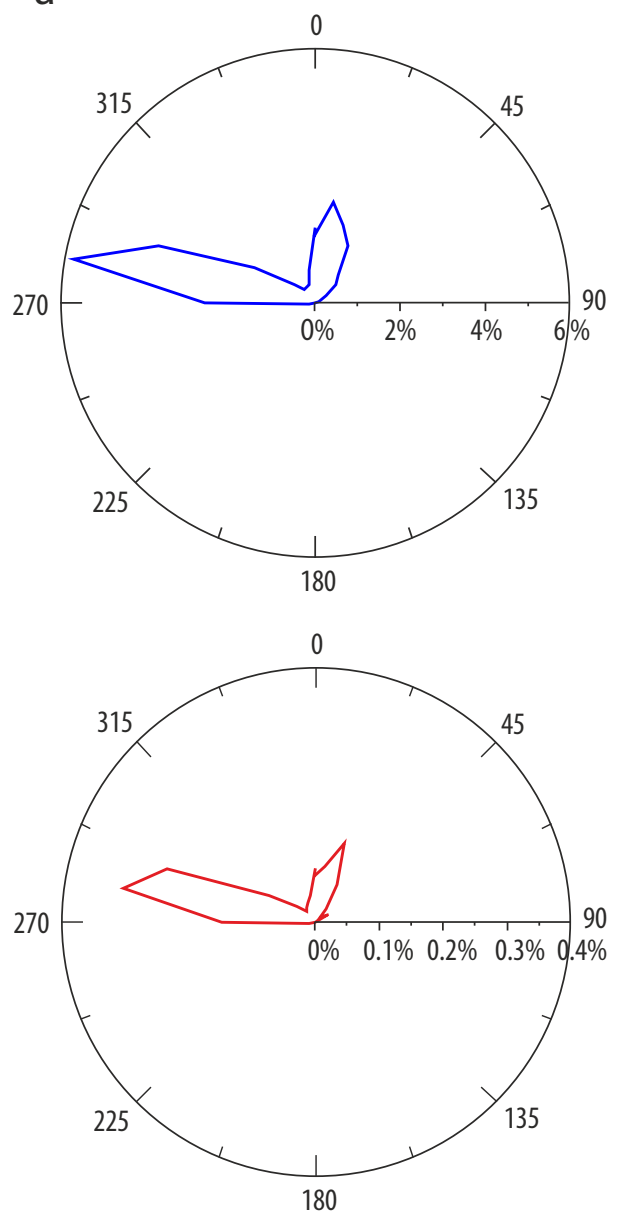

b
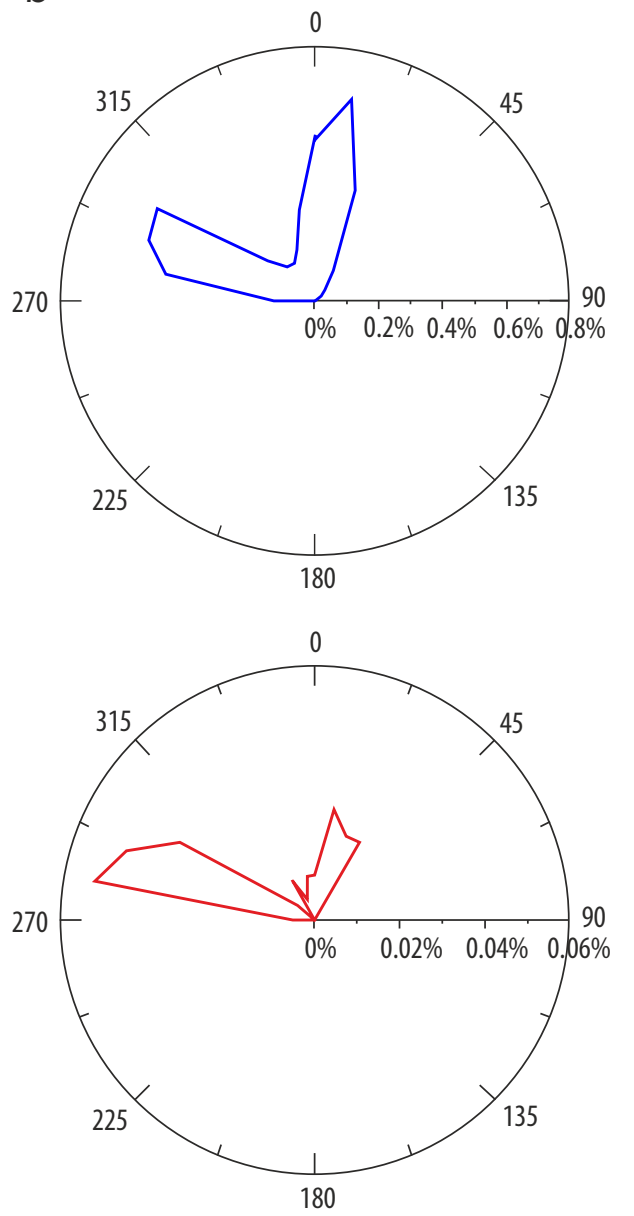

Figure 3. Wave rose for storm (blue) and extreme (red) waves from the Directional Waverider buoy measurements: (a) $H_{\mathrm{s}}>1 \mathrm{~m}$; (b) $H_{\mathrm{s}}>$ $2 \mathrm{~m}$. The peak direction is considered.

Figura 3. Rosa de oleaje para las olas generadas por tormentas (azul) y olas gigantes (rojo) a partir de las mediciones de una boya direccional tipo Waverider: (a) $H_{\mathrm{s}}>1 \mathrm{~m}$; (b) $H_{\mathrm{s}}>2 \mathrm{~m}$. Se considera la dirección predominante. 
Dally 1996). The significant wave height $\left(H_{\mathrm{s}}\right)$ and the mean wave period $\left(T_{\mathrm{m}}\right)$ are probably the most common parameters used to represent wave height and wave period in a wave record. Statistics of these parameters can be presented in the form of a bivariate histogram, where the number of cases $(N)$ is presented in a two-dimensional grid. Appropriate $H_{\mathrm{s}}-T_{\mathrm{m}}$ histograms for the storm wave records $(4,974)$ and the extreme wave records (261) are shown in Figure 4. The important feature of the histogram is the narrow range of wave periods for high values of $H_{\mathrm{s}}$, which enables us to estimate $T_{\mathrm{m}}$ for extreme sea states. The $T_{\mathrm{m}}$ value for the southern Baltic Sea is about $5 \mathrm{~s}$. The plots show that strong storms are characterized by a wider range of $T_{\mathrm{m}}$ values.

A different situation is observed in the bivariate $H_{\mathrm{s}}-T_{\mathrm{m}}$ histograms plotted for the storm and extreme wave records (Fig. 4). The plots are characterized by a wide range of mean wave lengths $\left(L_{\mathrm{m}}\right)$. The range of $L_{\mathrm{m}}$ values is relatively wide for both severe and extreme sea states. The wave lengths were calculated according to the linear dispersion relation for a given depth and wave period.

Extreme storms are related to higher waves. Wave steepness, together with wave height, is often used to represent higher waves. This dimensionless parameter is very popular los parámetros más comúnmente usados para representar la altura y periodo de las olas en un registro de oleaje. La estadística de estos parámetros puede presentarse en forma de un histograma bivariante, donde el número de casos $(N)$ se presenta en una cuadrícula bidimensional. En la Figura 4 se muestran histogramas de $H_{\mathrm{s}} v s T_{\mathrm{m}}$ para los registros de olas generadas por tormentas $(4,974)$ y los registros de olas extremas (261). Un punto importante del histograma es el estrecho intervalo de los periodos del oleaje para los valores altos de $H_{\mathrm{s}}$, lo que nos permite estimar $T_{\mathrm{m}}$ para los estados de mar extremos. Para el mar Báltico, el valor de $T_{\mathrm{m}}$ sería de alrededor de $5 \mathrm{~s}$. Las gráficas muestran que las tormentas fuertes están caracterizadas por un mayor intervalo de valores de $T_{\mathrm{m}}$.

Los histogramas bivariantes de $H_{\mathrm{s}} v s T_{\mathrm{m}}$ para los registros de tormentas y olas extremas muestran otra situación (Fig. 4). Las gráficas se caracterizan por un amplio intervalo de longitudes promedio de las olas $\left(L_{\mathrm{m}}\right)$. El intervalo de los valores de $L_{\mathrm{m}}$ es relativamente amplio tanto para estados de mar severos como extremos. Las longitudes se calcularon según la relación de dispersión lineal para una profundidad y periodo de oleaje dado.

Las tormentas se relacionan con olas más grandes, y frecuentemente se usa la inclinación de la ola junto con la altura a
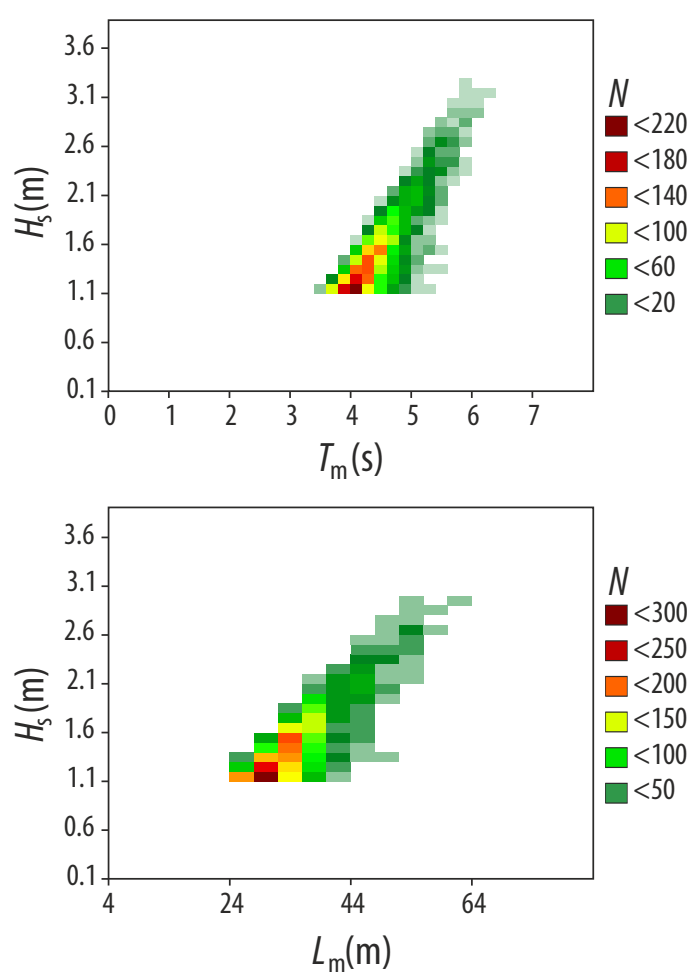

b
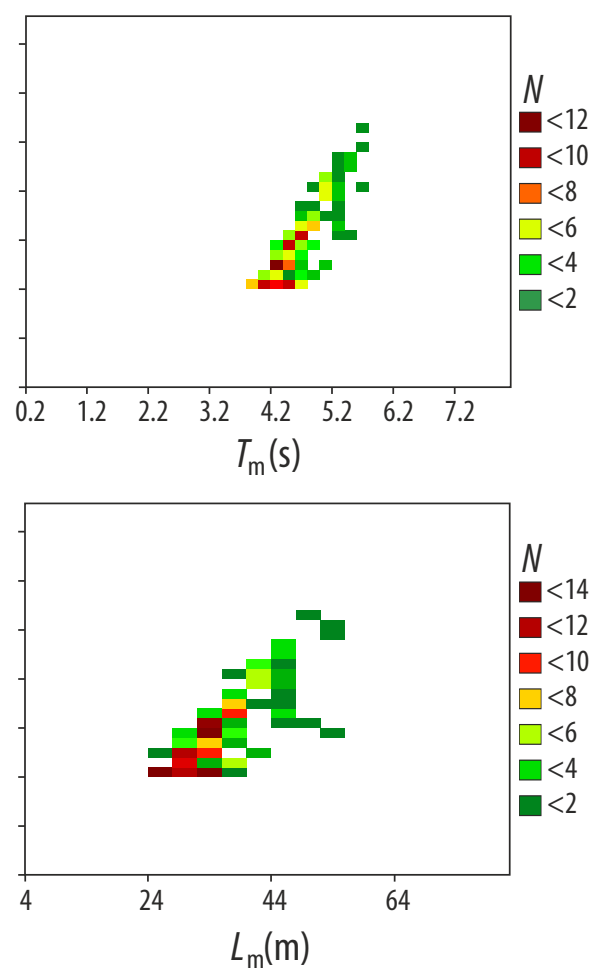

Figure 4. Bivariate histograms in terms of significant wave height $\left(H_{\mathrm{s}}\right)$ : (a) storm wave data set and $(\mathbf{b})$ extreme wave data set. $T_{\mathrm{m}}=$ mean wave period; $L_{\mathrm{m}}=$ mean wave length; and $N=$ number of cases.

Figura 4. Histogramas bivariantes en función de la altura significativa del oleaje $\left(H_{\mathrm{s}}\right)$ : $(\mathbf{a})$ conjunto de datos de olas generadas por tormentas y (b) conjunto de datos de olas gigantes. $T_{\mathrm{m}}=$ periodo promedio de las olas; $L_{\mathrm{m}}=$ longitud promedio de las olas; y $N=$ número de casos. 
and it is of interest to analyze wave steepness in the case of strong and extreme storms. An adequate analysis was performed for the available storm and extreme wave data sets. The relation between wave steepness and $T_{\mathrm{m}}$ is presented in Figure 5.

The plots in Figure 5 are characterized by a relatively wide scatter of the mean wave steepnesses $\left(S_{\mathrm{m}}\right)$ and $T_{\mathrm{m}}$ values. The results show that the distribution of $S_{\mathrm{m}}$ is similar for the storm and extreme sea states. This is probably due to the particular feature of wave steepness reaching similar values for waves of different height and length. de la ola para representar las olas más altas. Este parámetro adimensional es muy popular y resulta interesante para analizar la inclinación de las olas en el caso de tormentas fuertes y extremas. Se realizó un análisis para los conjuntos de datos disponibles de tormentas y olas extremas. La relación entre la inclinación de las olas y $T_{\mathrm{m}}$ se muestra en la Figura 5.

Las gráficas de la Figura 5 se caracterizan por una dispersión relativamente amplia de los valores de la inclinación promedio de las olas $\left(S_{\mathrm{m}}\right)$ y $T_{\mathrm{m}}$. Los resultados muestran que la distribución de la inclinación promedio es similar para los estados de mar tormentosos y extremos. Esto probablemente a
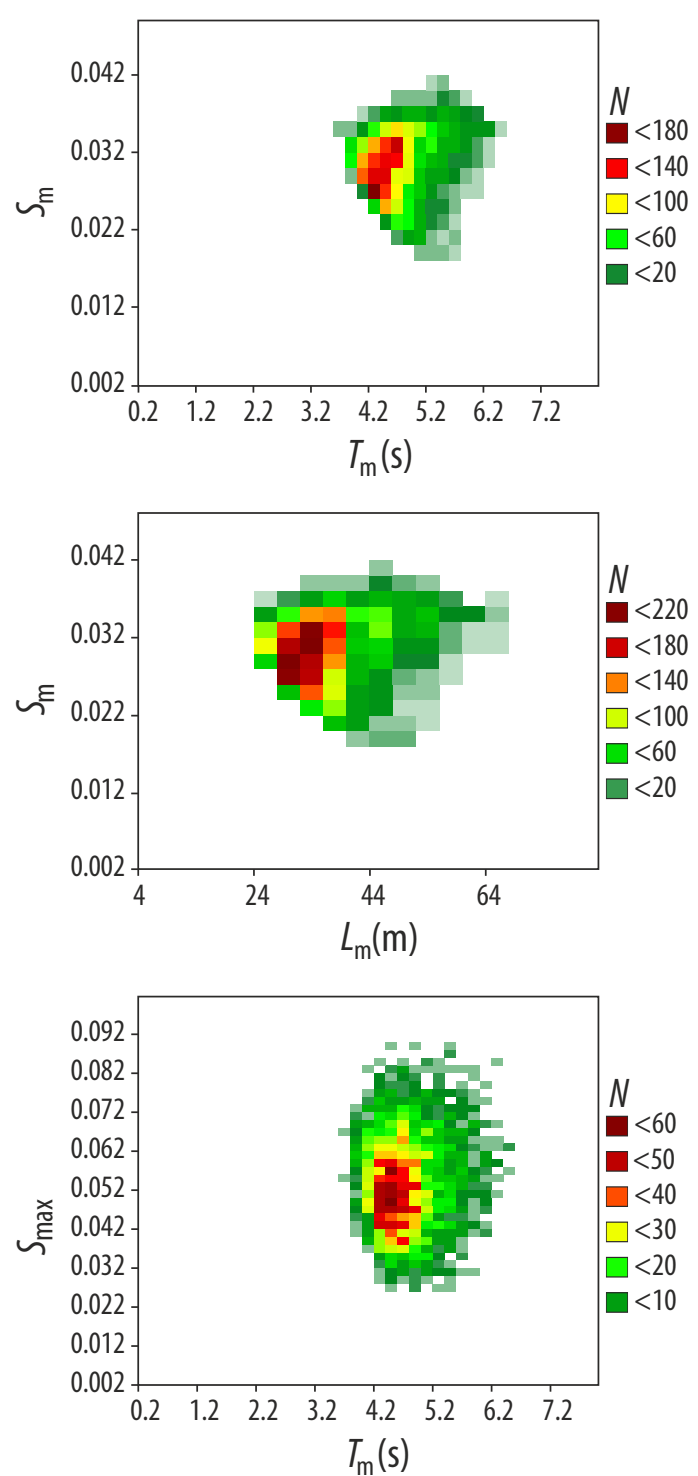

b
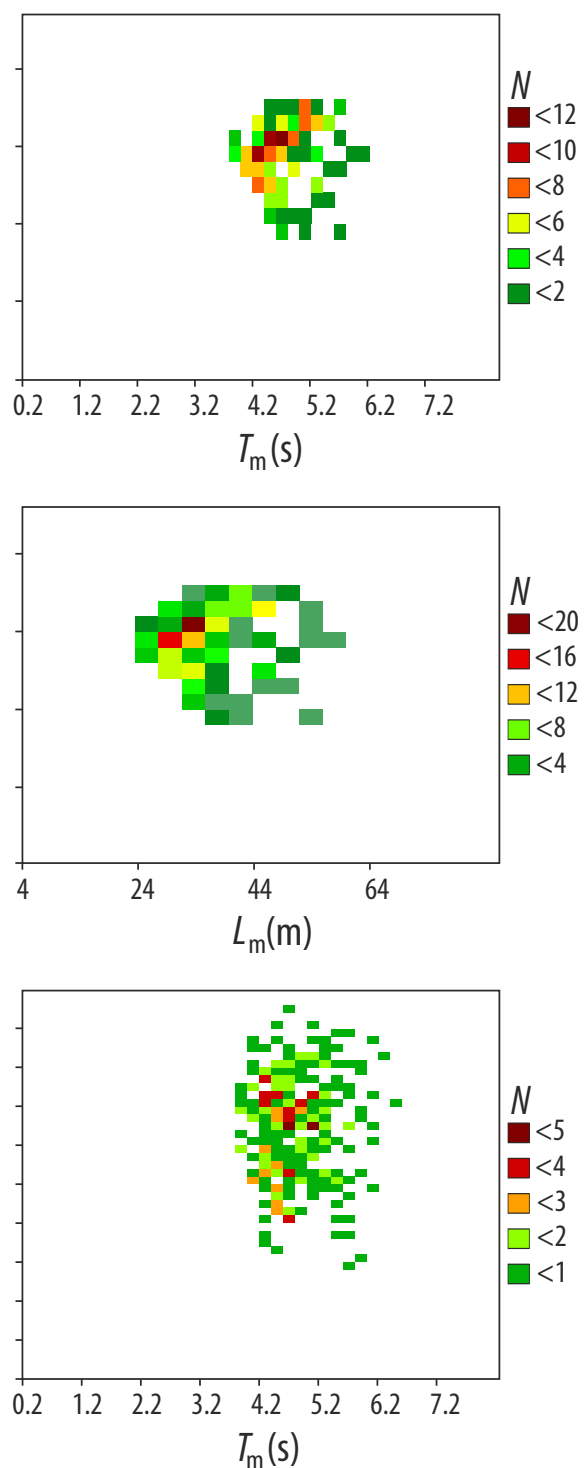

Figure 5. Bivariate histograms in terms of wave steepness $(S)$ : (a) storm wave data set and (b) extreme wave data set. $S_{\mathrm{m}}=$ mean wave steepness; $S_{\max }=$ maximum wave steepness; $T_{\mathrm{m}}=$ mean wave period; $L_{\mathrm{m}}=$ mean wave length; and $N=$ number of cases.

Figura 5. Histogramas bivariantes en función de la inclinación de la ola $(S)$ : (a) conjunto de datos de olas generadas por tormentas y (b) conjunto de datos de olas gigantes. $S_{\mathrm{m}}=$ inclinación promedio de las olas; $S_{\max }=$ máxima inclinación de las olas; $T_{\mathrm{m}}=$ periodo promedio de las olas; $L_{\mathrm{m}}=$ longitud promedio de las olas; y $N=$ número de casos. 
A similar situation is observed in the bivariate $S_{\mathrm{m}}-L_{\mathrm{m}}$ histograms (Fig. 5). It is worth noting that the presentation of results in terms of $L_{\mathrm{m}}$ instead of $T_{\mathrm{m}}$ has a limited effect on the final plots. Additional information on extreme storm features is provided by the bivariate $S_{\max }-L_{\mathrm{m}}$ histograms shown in Figure 5. The results are plotted for the storm and extreme wave data sets.

The plots in Figure 5 show a relatively wide scatter of the $T_{\mathrm{m}}$ values, as expected from previous analyses. However, the results show that the maximum wave steepness is far higher for the extreme wave data set than for the storm wave data set. The maximum wave steepness for the extreme wave records may reach the level of about 0.1 . A higher value of wave steepness may serve as an indication of the presence of extreme waves. It should be emphasized, however, that the above analysis was performed on the basis of a limited data set. Thus, the deduced conclusions cannot be generalized at this stage.

\section{Analysis of individual extreme wave records}

The available data set also provides the possibility of analyzing wave groups, correlation between waves, individual wave shapes, etc. The analysis was performed for extreme wave records and focused on records with a high $H_{\max } / H_{\mathrm{s}}$ ratio. Typical examples of wave records with high $H_{\max } / H_{\mathrm{s}}$ ratios and distinguished freak-type waves are presented in Figure 6. The plots illustrate strong deviations of freak waves from the average sea state. A significant deviation of freaktype waves from the average sea state makes these waves dangerous even for large vessels.

A successive example of a freak-type wave is shown in Figure 7. This is a particularly interesting case due to the extremely large $H_{\max } / H_{\mathrm{s}}$ ratio: $2.41 ; H_{\mathrm{s}}=2.57 \mathrm{~m}, H_{\max }=$ $6.2 \mathrm{~m}$. The wave buoy recorded this freak-type wave during a storm on 14 September 2002. These measurements indicate that the $H_{\max } / H_{\mathrm{s}}$ ratio may occasionally reach 3 . In fact, similar results have been reported in other studies on freak waves (Stansell 2004). Because $H_{\mathrm{s}}$ during strong storms in the Baltic Sea may reach $10 \mathrm{~m}$, or even higher values under favorable wave generation conditions (Soomere et al. 2008), freak-type waves during such storms may exceed $20 \mathrm{~m}$.

Freak-type waves have limited effects on wave energy spectrums that are usually multi-peaked, as indicated in Figure 8. Although more studies are required, the analysis conducted on the basis of our recent multi-point field measurements and laboratory experiments in a wave flume shows that the differences between spectrums with and without freak waves are negligibly small from a practical point of view. This is demonstrated by "subtracting" a freak wave from the wave record and conducting a spectral analysis. This is an important conclusion, because it indicates that the wave energy spectrum cannot be used to predict freak waves. A similar conclusion was derived in the MaxWave project on the basis of wind-wave records from different basins. se relaciona con la característica particular de que la inclinación de la ola alcanza valores similares para olas de diferente altura y longitud.

Se observa una situación similar en los histogramas bivariantes de $S_{\mathrm{m}} v s L_{\mathrm{m}}$ (Fig. 5). Cabe mencionar que la presentación de los resultados en términos de $L_{\mathrm{m}}$ en vez de $T_{\mathrm{m}}$ tiene un efecto limitado en las gráficas finales. Los histogramas bivariantes de $S_{\max }$ vs $L_{\mathrm{m}}$ (Fig. 5) muestran información adicional sobre las características de tormentas extremas. Los resultados se grafican para los conjuntos de datos de olas extremas y de tormentas.

Las gráficas de la Figura 5 muestran una dispersión relativamente amplia de los valores de $T_{\mathrm{m}}$, como se esperaba de análisis previos; sin embargo, los resultados indican que la máxima inclinación de las olas es mucho mayor para el conjunto de datos de olas extremas que para el conjunto de datos de olas generadas por tormentas. La inclinación máxima para los registros de olas extremas puede alcanzar un nivel de $\sim 0.1$. Un valor de inclinación más alto puede servir como una indicación de la presencia de olas extremas. No obstante, es importante mencionar que el análisis se realizó con base en un conjunto de datos limitados. Por lo tanto, las conclusiones deducidas no pueden generalizarse en este momento.

\section{Análisis de registros de olas gigantes individuales}

El conjunto de datos disponible permite analizar grupos de olas, la correlación entre olas, las formas de olas individuales, etc. El análisis se realizó para los registros de olas gigantes y se centró en los registros que mostraban una alta razón $H_{\max } / H_{\mathrm{s}}$. En la Figura 6 se muestran ejemplos típicos de registros con una alta razón $H_{\max } / H_{\mathrm{s}}$ que distinguen olas gigantes. Las gráficas muestran desviaciones de olas gigantes del estado de mar promedio. Una desviación importante de las olas gigantes del estado de mar promedio las hace peligrosas inclusive para embarcaciones grandes.

En la Figura 7 se muestra un ejemplo sucesivo de una ola gigante. Éste es un caso particularmente interesante debido a la muy elevada razón $H_{\max } / H_{\mathrm{s}}: 2.41 ; H_{\mathrm{s}}=2.57 \mathrm{~m}, H_{\max }=$ $6.2 \mathrm{~m}$. La boya registró esta ola gigante durante una tormenta el 14 de septiembre de 2002. Estas mediciones indican que la razón $H_{\max } / H_{\mathrm{s}}$ puede ocasionalmente alcanzar 3. En otros estudios de olas gigantes se han obtenido resultados similares (Stansell 2004). Ya que la $H_{\mathrm{s}}$ durante tormentas fuertes en el mar Báltico puede alcanzar los $10 \mathrm{~m}$, o valores más altos en condiciones favorables para la generación de olas (Soomere et al. 2008), las olas gigantes durante tales tormentas pueden sobrepasar los $20 \mathrm{~m}$ de altura.

Las olas gigantes tienen efectos limitados en los espectros de energía del oleaje que usualmente tienen picos múltiples, como se indica en la Figura 8. Aunque se requieren más estudios, el análisis realizado con base en mediciones de campo en varios sitios, y en experimentos de laboratorio en un canal de oleaje, muestra que las diferencias entre los espectros con $\mathrm{y}$ sin olas gigantes son muy pequeñas desde un punto de vista 

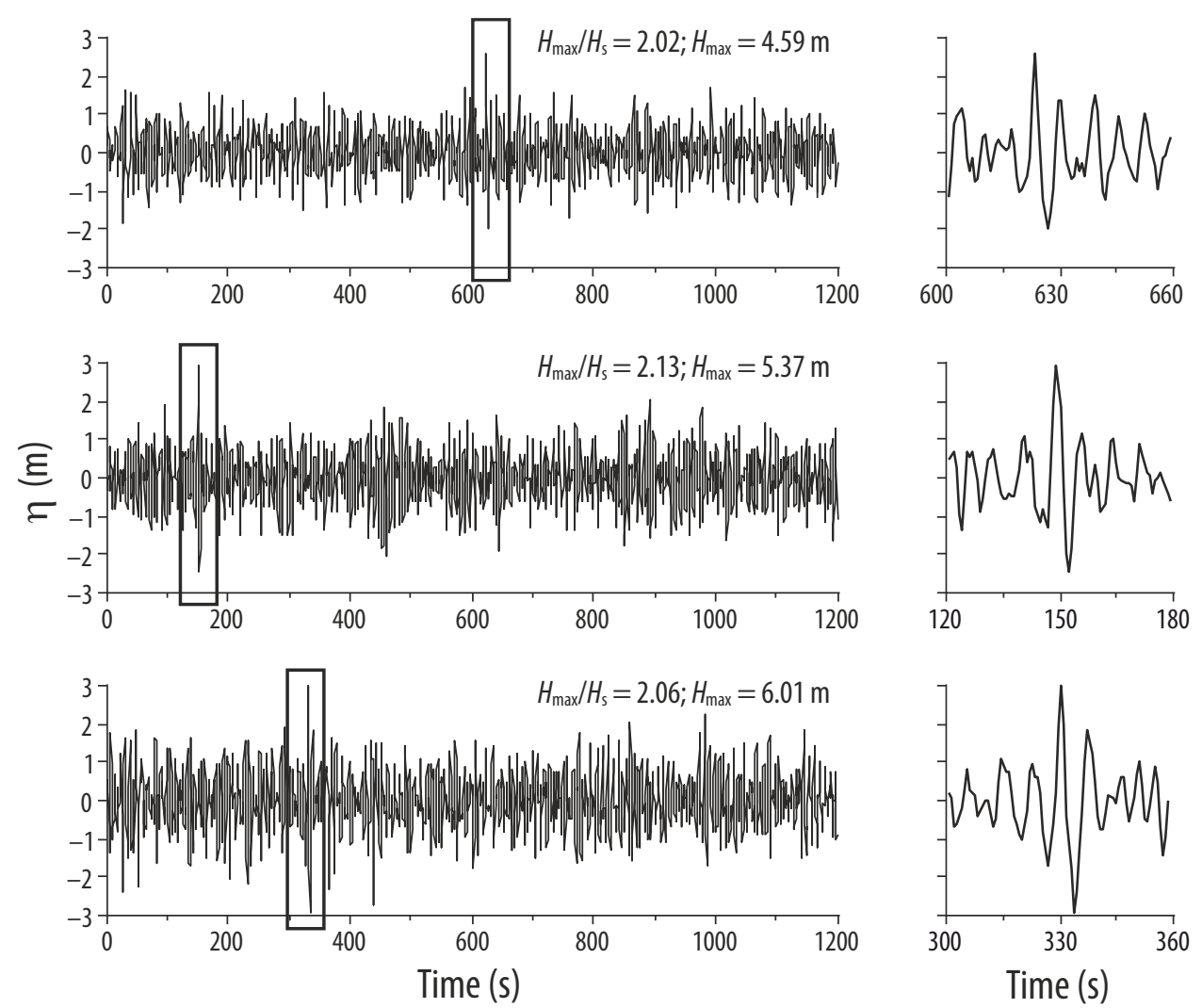

Figure 6. Examples of extreme wave records with freak-type waves. $H_{\max }=$ maximum wave height; $H_{\mathrm{s}}=$ significant wave height; and $\eta=$ free-surface elevation.

Figura 6. Ejemplos de registros de oleaje extremo con olas gigantes. $H_{\max }=$ altura máxima de las olas; $H_{\mathrm{s}}=$ altura significativa del oleaje; y $\eta=$ elevación de la superficie libre del mar.
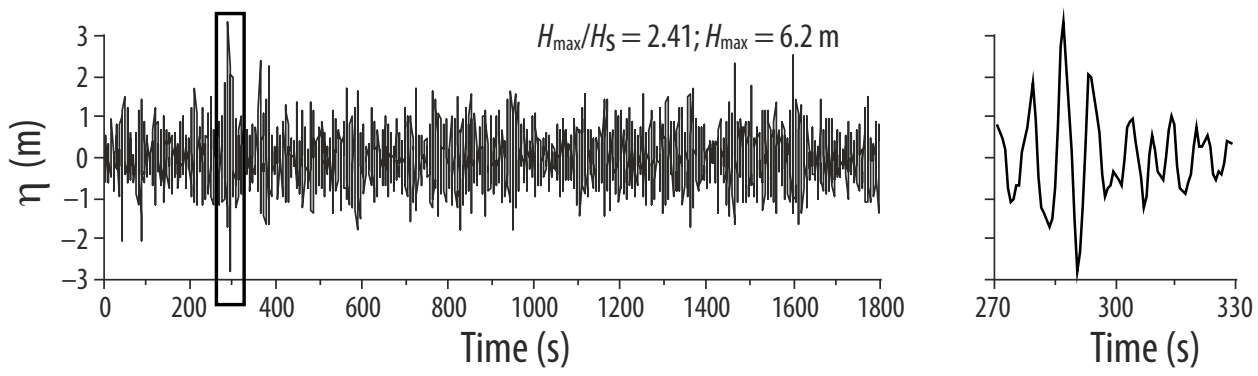

Figure 7. An extreme wave of large maximum to significant wave height ratio. $H_{\max }=$ maximum wave height; $H_{\mathrm{s}}=$ significant wave height; and $\eta=$ free-surface elevation.

Figura 7. Ola gigante con una alta relación entre la altura máxima y significativa de la ola. $H_{\max }=$ altura máxima de las olas; $H_{\mathrm{s}}=$ altura significativa del oleaje; y $\eta=$ elevación de la superficie libre del mar.

Moreover, the analysis indicates that higher order spectral moments cannot be used to predict freak waves, which is in accordance with a similar conclusion derived also for larger basins. This makes the research on extreme waves and warning systems a difficult task because wave energy spectrums are the main outcome of software used to predict wind waves worldwide. práctico. Esto se demuestra al "restar" una ola gigante del registro de oleaje y realizar un análisis espectral. Ésta es una conclusión importante, ya que indica que no se puede usar el espectro de energía del oleaje para predecir olas gigantes. El proyecto denominado MaxWave obtuvo una conclusión similar con base en registros del oleaje en diversas cuencas. Además, el análisis indica que no se pueden usar 
Since the work of Longuet-Higgins (1952), the Rayleigh distribution has been applied to describe the distribution of individual wave heights. Although the use of the Rayleigh distribution is not the most effective for the assessment of statistical properties of freak wave heights, it may serve for comparisons with the outcome of other studies on the probability of occurrence of extreme waves. The probability of occurrence of freak waves can be assessed by applying several distributions including Weibull, Gumbel, etc. (e.g., Goda 2000). In Figure 9, examples are presented of the probability of exceedance of waves for empirical data and corresponding results predicted by the Rayleigh cumulative distribution of wave heights $(H)$ :

$$
F(H)=1-\exp \left[-\frac{\pi}{4}\left(\frac{H}{\bar{H}}\right)^{2}\right]
$$

The plots in Figure 9 show that for $H>1.5 H_{\mathrm{s}}$, the predictions from the Rayleigh model become increasingly poor. The Rayleigh distribution underestimates the probability of exceedance of the largest waves in the extreme wave records, which is in opposition to the common expectation that it over-predicts the probability of occurrence of large wave heights measured in the sea (see, e.g., Stansell 2004). The use of the corrected Rayleigh distribution according to Næss (1985) or the Forristall wave height distribution (Forristall 1978) would result in an even larger disagreement in case of freak wave height statistics.

The Rayleigh distribution does not have an upper bound. The probability density decreases exponentially as the wave height increases, but never becomes zero (Goda 2000). Therefore, the largest wave height is a statistically defined quantity in such a manner that it is the largest value among the population of wave heights. Nevertheless, one has to momentos espectrales de mayor orden para predecir olas gigantes, lo que concuerda con una conclusión similar derivada para cuencas más grandes. Esto dificulta la investigación de olas gigantes y sistemas de alerta ya que los espectros de energía del oleaje son el principal producto de los programas de cómputo que se usan globalmente para predecir el oleaje.

A partir del trabajo de Longuet-Higgins (1952), se ha usado la distribución de Rayleigh para describir la distribución de las alturas de olas individuales. Aunque el uso de la distribución de Rayleigh no es la forma más efectiva de evaluar las propiedades estadísticas de las alturas de olas gigantes, puede servir para realizar comparaciones con los resultados de otros estudios en cuanto a la probabilidad de que ocurran olas extremas. La probabilidad de que ocurran olas gigantes puede evaluarse mediante la aplicación de varias distribuciones incluyendo las de Weibull, Gumbel, etc. (e.g., Goda 2000). En la Figura 9 se presentan ejemplos de la probabilidad de excedencia de olas para datos empíricos y los resultados correspondientes predichos por la distribución acumulativa de Rayleigh para la altura de las olas:

$$
F(H)=1-\exp \left[-\frac{\pi}{4}\left(\frac{H}{\bar{H}}\right)^{2}\right]
$$

Las gráficas de la Figura 9 muestran que para $H>1.5 H_{\mathrm{s}}$, las predicciones del modelo de Rayleigh se vuelven más pobres. La distribución de Rayleigh subestima la probabilidad de excedencia de las olas más grandes en el registro de olas extremas, lo cual es opuesto a la expectativa común de que sobrepredice la probabilidad de excedencia de las alturas de olas grandes medidas en el mar (ver, e.g., Stansell 2004). El uso de la distribución de Rayleigh corregida según Næss (1985) o la distribución de la altura del oleaje de Forristall
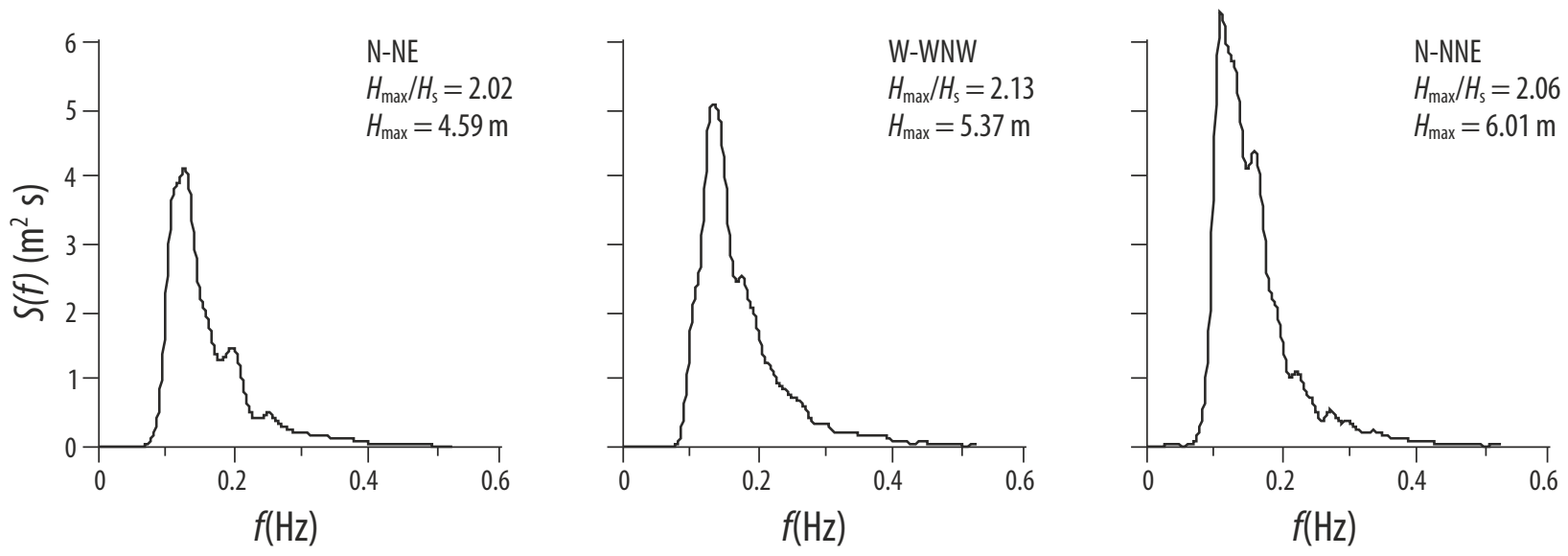

Figure 8. Wave energy spectra corresponding to extreme storms. $S(f)=$ spectral density and $f=$ frequency.

Figura 8. Espectros de energía del oleaje correspondientes a tormentas extremas. $S(f)=$ densidad espectral y $f=$ frecuencia. 

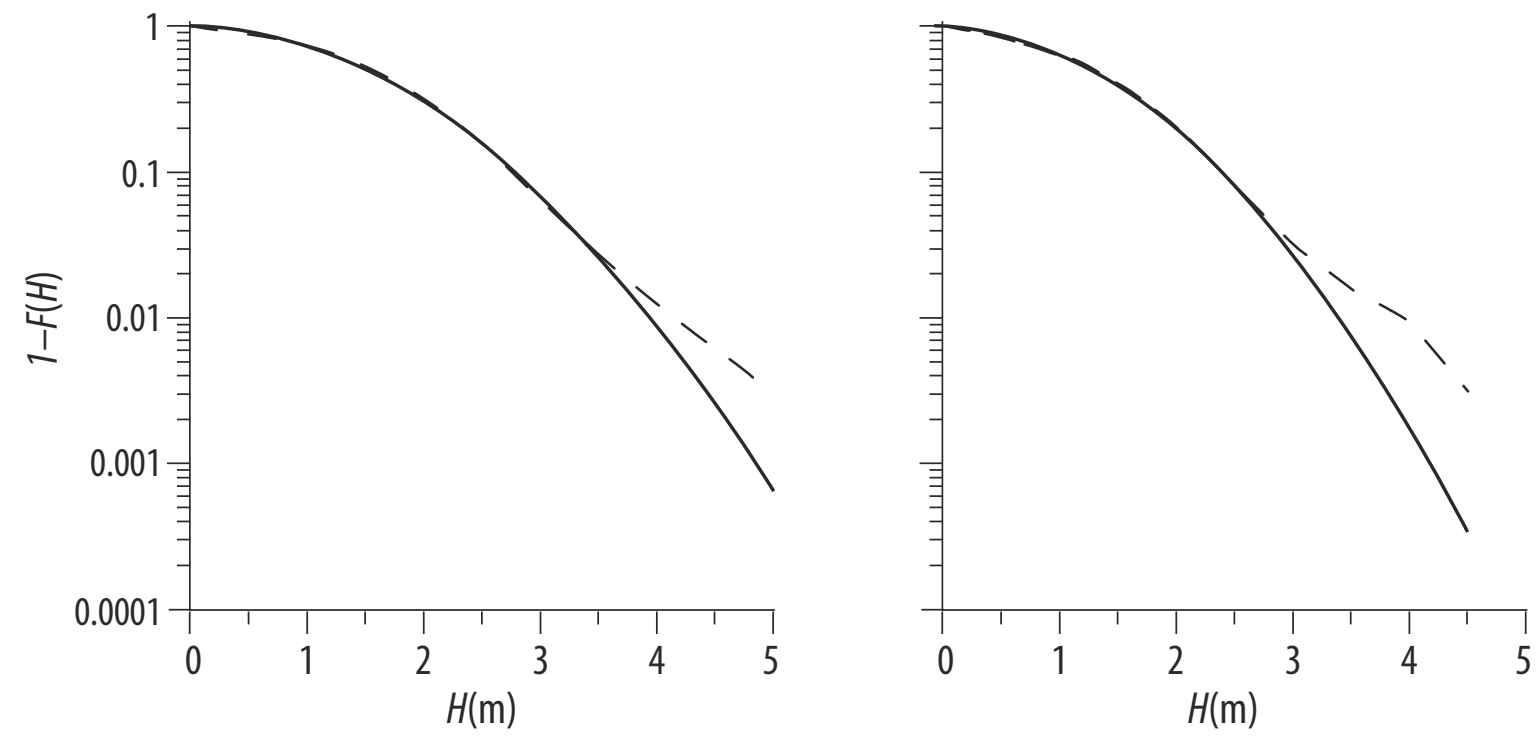

Figure 9. Probability of exceedance function for the extreme wave record: Rayleigh distribution (straight line); empirical distribution (dashed line). $F(H)=$ cumulative distribution and $H=$ wave height.

Figura 9. Función de probabilidad de excedencia para el registro de olas gigantes: distribución de Rayleigh (línea recta); distribución empírica (línea discontinua). $F(H)=$ distribución acumulativa y $H=$ altura de la ola.

remember that despite the drawbacks, the Rayleigh distribution and its modifications are widely applied by engineers and scientists and the results of the present study are a source of rare information of significant practical importance.

\section{Application of transform techniques}

The occurrence of extreme waves or extreme wave groups is often a highly non-stationary phenomenon. In order to investigate the structure of such waves, a proper method to analyze the temporal and spectral characteristics is required. Standard methods used for spectral analysis are inappropriate for studying non-stationary signals. The wavelet transform method has been proven to be an efficient tool in the analysis of extreme waves and extreme wave events. The method provides the wave energy distribution and enables localizing it simultaneously in the time and frequency domain (see, e.g., Massel 2001, Chien et al. 2002, Mori et al. 2002). The alternative time-frequency analysis techniques that could be applied to evaluate energy in non-stationary wave signals are, for example, the Smoothed Instantaneous Wave Energy History and Hilbert-Huang Transform (see, e.g., Funke and Mansard 1980, Huang and Shen 2005, Dong et al. 2015).

The wavelet transform method was applied to analyze several extreme wave records (Fig. 10). The results of the analysis of a record with extreme waves are presented in Figure 10a and the results of the analysis of an extreme wave record with more emphasis on wave groups are presented in Figure 10b. Both records refer to extreme storms that are usually characterized by multi-peaked wave energy spectrums.
(Forristall 1978) produciría una discordancia aún mayor en el caso de la estadística de la altura de olas gigantes.

La distribución de Rayleigh no tiene un límite superior. La densidad de probabilidad decrece exponencialmente conforme aumenta la altura del oleaje, pero nunca llega a ser cero (Goda 2000). Por lo tanto, la mayor altura del oleaje es una cantidad definida estadísticamente de tal manera que es el valor más alto de todas las alturas. No obstante, es necesario recordar que a pesar de las desventajas, la distribución de Rayleigh y sus modificaciones son ampliamente usadas por ingenieros y científicos, y que los resultados del presente estudio son una fuente de información de considerable importancia práctica.

\section{Aplicación de técnicas de transformación}

El acontecimiento de olas extremas o grupos de olas extremas frecuentemente es un fenómeno no estacionario. Para investigar la estructura de tales olas se requiere un método apropiado para analizar las características temporales y espectrales. Los métodos estándar usados para los análisis espectrales no son adecuados para estudiar señales no estacionarias. El método de transformación wavelet ha resultado ser una herramienta eficiente en el análisis de olas gigantes y eventos de oleaje extremos. El método proporciona la distribución de energía del oleaje y permite su localización simultánea en el dominio del tiempo y la frecuencia (ver, e.g., Massel 2001, Chien et al. 2002, Mori et al. 2002). Las técnicas de análisis tiempo-frecuencia alternativas que podrían usarse para evaluar la energía en señales no estacionarias son, por ejemplo, el registro instantáneo de energía 
The plots in Figure 10 show that the wavelet transform method detects extreme waves and extreme wave groups fairly well. A similar conclusion was derived in the MaxWave project on the basis of other wind-wave records from the Baltic Sea (Paprota et al. 2003). Obviously, the possibility of detecting extreme waves and wave groups is very important; however, from a practical point of view, we are more interested in a tool that can predict such extreme events.
(Smoothed Instantaneous Wave Energy History) y la transformada de Hilbert-Huang (ver, e.g., Funke y Mansard 1980, Huang y Shen 2005, Dong et al. 2015).

Se usó el método de transformación wavelet para analizar varios registros de olas gigantes (Fig. 10). Los resultados del análisis de un registro con olas extremas se presentan en la Figura 10a y los resultados del análisis de un registro de oleaje extremo con mayor énfasis en grupos de olas se
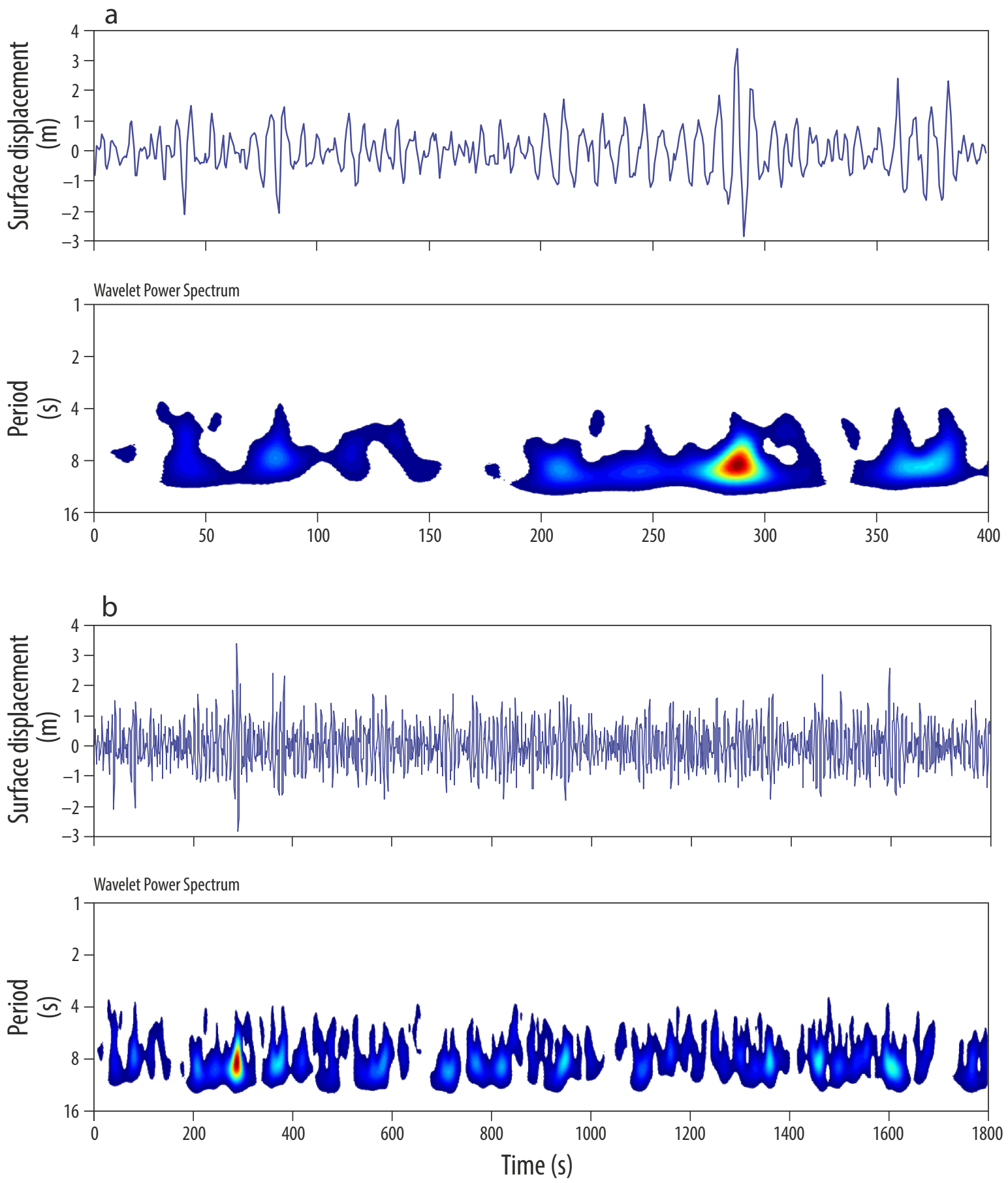

Figure 10. Wavelet transform analysis of extreme wave records.

Figura 10. Análisis de transformación wavelet de registros de olas gigantes. 
One should realize that despite some progress that has been made in the studies on freak waves, including present investigations, knowledge on the formation and physics of extreme waves and wave events is still incomplete. One of the problems is the type of available data that are basically limited to waves recorded by Waverider buoys, laser altimeters, and resistance-type wave gauges, and it is difficult to investigate the formation of freak waves, study their evolution and spatial characteristics, learn more about their physics, etc., from single-point wave records. Models and simulations derived on the basis of single-point wave records often provide misleading information on freak waves. There is an obvious need to conduct more studies on the origin and physics of extreme waves and wave events. Investigations should include multi-point wind-wave measurements to provide more information on the physics of freak waves, which may be helpful in developing theoretical models, tools, and finally warning systems.

\section{DISCUSSION}

Freak waves are unique and rare phenomena. They pose a threat to boats and even large vessels, as well as offshore and coastal structures. The problem is that available field data that provide insight into the origin and physics of freak waves are very limited. In the present study, a unique set of wave data comprising 19,025 wind-wave records from the southern Baltic Sea was analyzed to provide information on the occurrence, parameters, and prevailing conditions of the formation of freak waves.

The analysis of the wind-wave records revealed a large number of extreme wave and wave events, including waves exceeding $12 \mathrm{~m}$ in height. The results show that strong storms with extreme waves come mainly from the W-WNW and N-NNE. This is an interesting and rather non-intuitive outcome. However, a wide range of analyses conducted on wind-wave records do not show any significant effect of freak waves on storm wave characteristics and description. The present analysis shows that a freak-type wave has a weak effect on wave spectrums, higher-order spectral moments, wave instability indexes, etc., and it is hard to detect or predict it from these quantities, which is challenging, because these hazardous waves may exceed $20 \mathrm{~m}$ even in the Baltic Sea. The study implies a need for multi-point wind-wave measurements to provide more information about the nature of freak waves.

One should realize that despite considerable progress made in studies on freak waves, including the progress made in recent years, the mechanisms of the formation and physics of extreme waves and wave events still require more investigation. Available data are basically limited to waves recorded by waveriders, laser altimeters, and resistance-type wave gauges, and it is difficult to investigate the formation of freak waves, study their evolution and spatial characteristics, learn more about their physics, etc., from single-point wave presenta en la Figura 10b. Ambos registros corresponden a tormentas extremas que normalmente están caracterizadas por espectros de energía con varios picos. Las gráficas de la Figura 10 muestran que el método de transformación wavelet detecta olas extremas y grupos de olas extremas bastante bien. El proyecto denominado MaxWave obtuvo una conclusión similar con base en otros registros del oleaje del mar Báltico (Paprota et al. 2003). Obviamente la posibilidad de detectar olas y grupos de olas gigantes es muy importante; sin embargo, desde un punto de vista práctico, es de mayor interés encontrar una herramienta que puede predecir eventos extremos.

A pesar de los avances logrados en los estudios de olas gigantes, el conocimiento de la formación y física de tales olas y de eventos de oleaje extremos aún es incompleto. Uno de los problemas es que los datos disponibles básicamente se limitan a registros obtenidos con boyas de tipo Waverider, altímetros de láser y medidores de olas de tipo resistencia, y es difícil de estudiar la formación de olas gigantes, su evolución, características espaciales, física, etc., de registros de un solo punto. Los modelos y simulaciones derivadas a partir de los registros del oleaje de un solo punto frecuentemente proporcionan información engañosa. Es necesario realizar más estudios del origen y la física de olas gigantes y eventos de oleaje extremos. Los estudios deberían incluir mediciones de oleaje de distintos sitios para recabar más información sobre la física de las olas gigantes, lo cual podría ayudar a desarrollar modelos teóricos, herramientas y un sistema de predicción y advertencia.

\section{DISCUSIÓN}

Las olas gigantes son fenómenos únicos y poco frecuentes, y representan una amenaza para los barcos, incluso los grandes, y para estructuras costeras y en alta mar; sin embargo, los datos de campo que proporcionan información sobre su origen y física son muy limitados. En el presente trabajo, analizamos un conjunto de 19,025 registros del oleaje en la parte sur del mar Báltico para recabar información sobre la frecuencia de olas gigantes, sus parámetros y las condiciones para su formación.

El análisis mostró que se registraron un número considerable de eventos de oleaje extremos y de olas gigantes, incluso olas de más de $12 \mathrm{~m}$ de altura. Las tormentas fuertes con olas extremas provienen del W-WNW y N-NNE. Éste es un resultado interesante y no intuitivo. No obstante, varios análisis de registros del oleaje no muestran efectos significativos de las olas gigantes en las características y descripción de las olas generadas por tormentas. El presente estudio muestra que una ola gigante tiene un efecto débil en los espectros de oleaje, momentos espectrales de mayor orden, índices de inestabilidad, etc., y resulta difícil detectarla o predecirla de estas cantidades, lo cual es un reto ya que estas olas peligrosas pueden sobrepasar los $20 \mathrm{~m}$ de altura inclusive en el mar Báltico. El estudio muestra que es necesario 
records. Models and simulations adjusted to single-point wave measurements are often sources of misleading information on freak waves. More studies on the origin and physics of extreme waves and wave events are needed. These studies should include multi-point wind-wave measurements to provide more information and eventually develop a prediction tool that can be applied to issue a warning against extreme waves or wave events.

\section{ACKNOWLEDGMENTS}

Financial support for this study was provided by the National Science Centre, Poland, and the Institute of HydroEngineering of the Polish Academy of Sciences under contract No. UMO-2012/05/13/ST8/01833. The authors are indebted to Barbara Paplińska for her valuable contributions to this study and to Rafał Ostrowski for providing access to complementary wind-wave data.

\section{REFERENCES}

Adcock TAA, Taylor PH. 2014. The physics of anomalous ('rogue') ocean waves. Rep. Prog. Phys. 77: 105901.

Bitner-Gregersen EM, Toffoli A. 2012. On the probability of occurrence of rogue waves. Nat. Hazards Earth Syst. Sci. 12: $751-762$

Chabchoub A, Hoffmann N, Onorato M, Akhmediev N. 2012. Super rogue waves: Observation of a higher-order breather in water waves. Phys. Rev. X 2: 011015.

Chien H, Kao CCK, Chuang LZH. 2002. On the characteristics of observed coastal freak waves. Coast. Eng. J. 44: 301-319.

Didenkulova I. 2010. Shapes of freak waves in the coastal zone of the Baltic Sea (Tallinn Bay). Boreal Environ. Res. 16: 138-148.

Didenkulova I, Pelinovsky E. 2011. Rogue waves in nonlinear hyperbolic systems (shallow-water framework). Nonlinearity 24: R1.

Dong S, Wang N, Lu H, Tang L. 2015. Bivariate distributions of group height and length for ocean waves using Copula methods. Coast. Eng. 96: 49-61.

Forristall GZ. 1978. On the statistical distribution of wave heights in a storm. J. Geophys. Res. 83: 2353-2358.

Funke ER, Mansard EPD. 1980. On the synthesis of realistic sea states in laboratory flume. In: Proceedings of the 17th International Conference on Coastal Engineering ASCE, Vol. 3, pp. 2974-2991.

Goda Y. 2000. Random seas and design of maritime structures. Advanced Series on Ocean Engineering, Vol. 15. World Scientific, Singapore, $464 \mathrm{pp}$.

Gramstad O, Trulsen K. 2007. Influence of crest and group length on the occurrence of freak waves. J. Fluid Mech. 582: 463-472.

Huang NE, Shen SSP. 2005. Hilbert-Huang Transform and its applications. Interdisciplinary Mathematical Sciences, Vol. 5. World Scientific, Singapore, $324 \mathrm{pp}$.

Kharif C, Pelinovsky E, Slunyaev A. 2009. Rogue Waves in the Ocean. Advances in Geophysical and Environmental Mechanics and Mathematics. Springer-Verlag, Berlin, 216 pp.

Leyden VM, Dally WR. 1996. Probabilistic modeling of long-term wave climate. In: Proceedings of the 25th International Conference on Coastal Engineering ASCE, Vol. 1, pp. 808-821. analizar mediciones del oleaje en varios sitios para obtener mayor información de la naturaleza de olas gigantes.

A pesar de los avances logrados en los estudios de olas gigantes, el conocimiento de la formación y física de tales olas y de eventos de oleaje extremos aún es incompleto. Los datos disponibles básicamente se limitan a registros obtenidos con boyas de tipo Waverider, altímetros de láser y medidores de olas de tipo resistencia, y es difícil de estudiar la formación de olas gigantes, su evolución, características espaciales, física, etc., de registros de un solo punto. Los modelos y simulaciones derivadas a partir de los registros del oleaje de un solo punto frecuentemente proporcionan información engañosa. Es necesario realizar más estudios del origen y la física de olas gigantes y eventos de oleaje extremos. Los estudios deberían incluir mediciones de oleaje de distintos sitios para recabar mayor información y poder desarrollar modelos teóricos, herramientas y un sistema de predicción y advertencia.

\section{Agradecimientos}

Este trabajo fue apoyado por el Centro Nacional de Ciencias, Polonia, y el Instituto de Hidroingeniería de la Academia de Ciencias de Polonia, bajo el contrato No. UMO-2012/05/13/ST8/01833. Los autores agradecen a Barbara Paplińska su valiosa contribución al estudio y a Rafał Ostrowski, quien nos facilitó datos complementarios.

Traducido al español por Christine Harris.

Longuet-Higgins MS. 1952. On the statistical distribution of the heights of sea waves. J. Mar. Res. 11: 245-266.

Magnusson AK, Donelan MA, Drennan WM. 1999. On estimating extremes in an evolving wave field. Coast. Eng. 36: 147-163. http://dx.doi.org/10.1016/S0378-3839(99)00004-6

Majewski D, Stachurska B, Sulisz W. 2014. Investigation of the effect of current on the formation of freak waves. In: Application of Physical Modelling to Port and Coastal Protection. Book of Proceedings of the 5th International Conference Coastlab 14, Vol. 1, pp. 153-160.

Massel SR. 2001. Wavelet analysis for processing of ocean surface wave records. Ocean Eng. 28: 957-987.

Montoya RD, Osorio Arias A, Ortiz Royero JC, Ocampo-Torres FJ. 2013. A wave parameters and directional spectrum analysis for extreme winds. Ocean Eng. 67: 100-118.

Mori N, Liu PC, Yasuda T. 2002. Analysis of freak wave measurements in the Sea of Japan. Ocean Eng. 29: 1399-1414.

Næss A. 1985. The joint crossing frequency of stochastic processes and its application to wave theory. Appl. Ocean Res. 7: 35-50.

Onorato M, Osborne AR, Serio M, Cavaleri L, Stansberg CT. 2006. Extreme waves, modulational instability and second order theory: Wave flume experiments on irregular waves. Eur. J. Mech. B/Fluids 25: 586-601.

Onorato M, Residori S, Bortolozzo U, Montina A, Arecchi FT. 2013. Rogue waves and their generating mechanisms in different physical contexts. Phys. Rep. 528: 47-89. 
Paplińska-Swerpel B, Paszke Ł, Sulisz W, Bolaños R. 2007. Application of statistical methods for the prediction of extreme wave events. J. Hydraul. Res. 46: 314-323.

Paprota M, Przewłócki J, Sulisz W, Swerpel BE. 2003. Extreme waves and wave events in the Baltic Sea. In: Rogue waves: Forecast and Impact on Marine Structures. GKSS Printing Office, Geesthacht, Germany

Rosenthal W, Lehner S. 2008. Rogue waves: Results of the MaxWave Project. J. Offshore Mech. Arct. Eng. Trans. ASME 130: 21006-21013.

Sergeeva A, Pelinovsky E, Talipova T. 2011. Nonlinear random wave field in shallow water: Variable Korteweg-de Vries framework. Nat. Hazards Earth Syst. Sci. 11: 323-330.

Silva R, Govaere G, Salles P, Bautista G, Diaz G. 2002. Oceanographic vulnerability to hurricanes on the Mexican coast. In: Proceedings of 6th International Workshop on Wave Hind Casting and Forecasting (Melbourne), pp. 137-151.

Soomere T, Behrens A, Tuomi L, Nielsen W. 2008. Wave conditions in the Baltic Proper and in the Gulf of Finland during windstorm Gudrun. Nat. Hazards Earth Syst. Sci. 8: 37-46.

Stansell P. 2004. Distributions of freak wave heights measured in the North Sea. Appl. Ocean Res. 26: 35-48.

Sulisz W, Paprota M. 2005. Analysis of wave parameters in extreme wave records. In: Maritime Transportation and Exploitation of
Ocean and Coastal Resources. Proceedings of the 12th International Congress of the International Maritime Association of the Mediterrenean, Lisbon, Portugal, Vol. 2, pp. 1153-1158.

Sulisz W, Paprota M. 2006. Laboratory investigation of the formation of freak waves. In: Proceedings of the 1st International Conference on the Application of the Physical Modelling to Port and Coastal Protection, Porto, Portugal, pp. $127-138$.

Sulisz W, Paprota M. 2011. Modeling of the propagation and evolution of nonlinear waves in a wave train. Arch. Mech. 63: 311-335.

Sulisz W, Paprota M. 2013. Modelling of the propagation and transformation of transient nonlinear waves on a current. China Ocean Eng. 27: 579-592.

Toffoli A, Bitner-Gregersen EM, Osborne AR, Serio M, Monbaliu J, Onorato M. 2011. Extreme waves in random crossing seas: Laboratory experiments and numerical simulations. Geophys. Res. Lett. 38: L06605.

Tucker M.J. 1991. Waves in Ocean Engineering, Measurements, Analysis, Interpretation. Ellis Horwood, New York, 431 pp.

Xiao W, Liu Y, Wu G, Yue DKP. 2013. Rogue wave occurrence and dynamics by direct simulations of nonlinear wave-field evolution. J. Fluid Mech. 720: 357-392.

Received November 2015, accepted May 2016. 